\title{
Edinburgh breast education campaign on breast cancer and breast self-examination: was it worth while?
}

\author{
M MAUREEN ROBERTS, ${ }^{1}$ SUSAN E ROBINSON, ${ }^{1}$ KATE FRENCH, ${ }^{1}$ ANN \\ PROUDFOOT, ${ }^{1}$ HELEN TALBOT, ${ }^{2}$ AND ROBERT A ELTON ${ }^{3}$ \\ From the Edinburgh Breast Screening Clinic and Department of Clinical Surgery, ${ }^{1}$ Regional Computing Centre, ${ }^{2}$ \\ and Medical Computing and Statistics Unit, ${ }^{3}$ University of Edinburgh
}

SUMMARY A health education campaign was carried out at the start of a large trial of screening for breast cancer in Edinburgh. After preliminary studies the campaign concentrated on talks to small groups of women by specially trained health visitors. Over a year, 12000 women attended. Systematic evaluation after 12 months showed that selected women who heard the talks were more knowledgeable about breast cancer, and a random sample of women in Edinburgh had a small but significant improvement in knowledge compared with women in Aberdeen. However, the random sample did not report an increase in the practice of breast self-examination (BSE) and there was no increase in workload for general practitioners. It is suggested that BSE is more likely to be accepted if combined with a physical examination.

When setting up a large randomised trial of screening for breast cancer in Edinburgh, we considered it important to carry out a health education campaign in parallel. ${ }^{12}$ We believed, like the American National Cancer Institute Working Group, that screening should be tested within a well-informed population. ${ }^{3}$ We were also concerned about the high proportion $(30 \%)$ of British women with breast cancer who present with advanced local disease.

In the health education campaign, we undertook to provide accurate background information for women, to increase awareness of the problems of breast cancer, and also to promote breast self-examination, but without increasing fear or anxiety. Unlike screening in the trial, which is offered to only half of the women aged 45-65 years of age in the city, the health education campaign was made available to all women in the city regardless of age or their inclusion in the randomised trial. We carried out two preliminary studies to determine how the campaign should be run, and to guide us in its content. Both these studies have been reported in full elsewhere, ${ }^{45}$ Briefly, a study based on group discussions indicated that communication should be through personal contact in small group meetings, as considerable support is necessary when promoting information about a subject as threatening as breast cancer. The second study, based on a random survey of women in Edinburgh and Aberdeen, showed that most were not well informed and that the level of knowledge was related to age and socioeconomic status.
From the beginning we incorporated plans to evaluate the effectiveness of the campaign. This paper describes the results of our evaluation studies, which, because of the constraints of our funding, were carried out after only 12 months of intensive activity.

\section{Description of campaign}

\section{AIMS}

In educational terms, our objectives were: (a) Cognitive: to increase women's knowledge of the breast, breast cancer, and the techniques of selfexamination, and to dispel commonly held misconceptions. (b) Affective: to raise the level of awareness about breast cancer, and to encourage positive attitudes towards early detection and treatment without creating anxiety, pessimism or avoidance. (c) Behavioural: to encourage the practice of monthly breast self-examination in a recommended way and to emphasise the importance of early reporting of any change or suspected abnormality.

\section{EDUCATIONAL CONTENT AND MATERIALS}

The "key messages" of our campaign are as listed in table 1 . Using these, a leaflet was designed and printed, and a standard talk was prepared. In both, the wording was extensively discussed and researched. The talks, illustrated by slides, were given by specially trained health visitors. This method allowed direct contact between speaker and audience, and discussion was encouraged. The speakers were familiar with 
Table 1 Key messages on which the leaflet and the talk were based

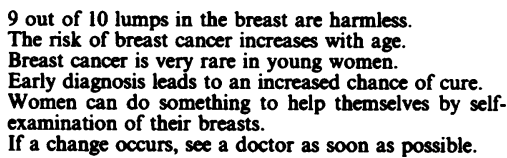

current methods of diagnosis and treatment and themselves attended continuing educational sessions.

Although we promoted the concept of early diagnosis of breast cancer, we could not promote screening as beneficial in view of the co-existence of the randomised trial. We therefore included information on the reasons for the trial and answered questions freely.

\section{COMMUNICATION METHODS}

Our intention was to speak to as many women as possible in the city. Of 200 personnel and industrial medical officers to whom we wrote explaining the campaign and offering speakers, 192 agreed, and 530 talks were given during work time. All known women's organisations were also contacted, leading to 84 talks. Altogether, we had a total audience of 12100 women, or approximately 20 women on average for each talk, during the 12 month period.

Our leaflets were distributed to all clinics and GP surgeries throughout the city. With the cooperation of the general practitioners, 18000 leaflets were sent to all women aged 45-65 years in those practices designated as controls within the screening trial. Women attending the screening clinic were also given the leaflet and taught breast self-examination on an individual basis as well as being screened. As the adult female population of Edinburgh is about 150000 , it is likely that we made some kind of contact with about $25 \%$ of women in the city.

We also obtained some low key publicity from the local press and radio, in order to promote the uptake of talks and to reach women not at work or in established groups. A small number of television programmes also occurred, mainly in response to national publicity.

\section{Evaluation of campaign-methods}

Evaluation was carried out in three stages: firstly, we checked whether the talk was understood and its messages retained by the individual; secondly, we used random surveys to assess diffusion of knowledge through the community; and, thirdly, we examined health service implications (as a possible measure of change in behaviour).

\section{WERE THE TALKS UNDERSTOOD AND} REMEMBERED?

Two studies were carried out to test short and long-term understanding.
(1) Early in the campaign self completion questionnaires, involving simple questions relating to the content of the talk, were used in a few consecutive groups of women before and immediately after the talk, to establish whether it should be modified.

(2) In order to test whether messages were retained for a year, a series of women clerical and domestic workers employed by the Regional Council were given questionnaires before, and 12 months after, their attendance at a talk. The questions were designed to test knowledge of the breast and breast selfexamination.

\section{DID THE CAMPAIGN HAVE ANY EFFECT ON} THE POPULATION?

The aim of this, our major evaluative study, was to determine the level of change in knowledge and the practice of breast self-examination in the community exposed to our campaign. To overcome the problem of chance temporal changes, similar surveys were carried out at the same time in another city, Aberdeen, in which there was no particular health education activity related to breast disease. The first survey, in a sample of women selected randomly from the electoral roll, was in May 1981, immediately before the start of the campaign in Edinburgh. ${ }^{4}$ The second survey was carried out one year later. To avoid interviewer effect, all women who had been surveyed the previous year were excluded, and a random sample was drawn from the rest of the female population of the two cities. In both, women aged 18-65 years were interviewed, using structured questionnaires, by experienced interviewers from Social and Community Planning Research (SCPR). The main core of questions was the same in both, but there were additional questions in the second survey about exposure to the campaign.

The level of knowledge about the breast and breast cancer, and the practice and technique of breast self-examination, was assessed by the questionnaire in relation to age and socioeconomic status and to other preventive health behaviour.

\section{IMPACT ON NHS-DID CONSULTATIONS INCREASE?}

This will be the subject of a future paper, but, briefly, a group of GPs were asked to monitor consultations over a period of time before and during the campaign. There was no evidence of any increase.

\section{STATISTICAL METHODS}

Changes in score for women interviewed twice were tested by Wilcoxon signed-rank test or chi-squared tests. The data from the population surveys in Edinburgh and Aberdeen were analysed by multiple logistic regression for individual questions or by multiple linear regression for overall scores. In these 
analyses, city, year, age group, and social class were included as explanatory variables, and also the interaction between city and year of survey. This last factor was used to test whether or not the change in response (proportion answering correctly or overall score) between 1981 and 1982 was significantly different in the two cities, within age groups and social classes.

\section{Evaluation of campaign $\longrightarrow$ results}

\section{UNDERSTANDING THE TALKS}

\section{(1) Short term}

A total of 92 women completed the questionnaire before and immediately after the talk. Of these, 74 had an increase in correct answers to questions and only one showed a decrease immediately after the talk. There was a significant increase in the number of women scoring more than $50 \%$ of correct answers: the number rose from 20 to $76 \%$ immediately after the talk $(\mathrm{p}<0.001)$.

These results gave us confidence in our methods but also enabled us to change the emphasis in some aspects of the talk for further clarification.

\section{(2) Long term}

Altogether, 260 women who had attended the talks and had completed the pre-teaching questionnaire were followed up a year later by postal questionnaire. A total of $183(70 \%)$ replied. The results of the preand post-teaching questionnaires are shown in table 2 for these 183 women. There was a significant increase in knowledge at one year compared with the preteaching level: 99 women increased their score and only 35 women had a decrease $(p<0.001)$. The number of women who tried examining their own breasts rose from 60 to $83 \%(p<0.001)$, and the number who felt reassured after breast selfexamination rose from $70.5 \%$ to $77.6 \%(p<0.05)$.

\section{EFFECT ON POPULATION: RANDOM SURVEY RESULTS}

Altogether, 1663 women were interviewed, 398 and 408 in Edinburgh in 1981 and 1982 respectively: 412 and $\mathbf{4 4 5}$ in Aberdeen. There were slight differences in age and social class distribution within the samples, both between cities and between surveys.

\section{(1) General knowledge about the breast}

The numbers, and percentage change, of women answering correctly the questions about the breast and breast cancer are shown in table 3, comparing the two cities over the 12-month period. The changes are small and not significantly different even when multiple logistic analysis was carried out, taking account of age and social class.

Table 2 Numbers of women achieving different "score" levels. before and 12 months after attending the talk

\begin{tabular}{|c|c|c|c|c|}
\hline \multirow[t]{2}{*}{ Score* } & \multicolumn{2}{|c|}{ Pre-teaching } & \multicolumn{2}{|c|}{ Post-teaching } \\
\hline & No. & $\%$ & No. & $\%$ \\
\hline $\begin{array}{l}0 \\
1 \\
2 \\
3 \\
4 \\
5 \\
6\end{array}$ & $\begin{array}{r}4 \\
20 \\
49 \\
50 \\
41 \\
12 \\
7\end{array}$ & $\begin{array}{r}2.2 \\
10.9 \\
26.8 \\
27.3 \\
22.4 \\
6.6 \\
3.8\end{array}$ & $\begin{array}{r}1 \\
6 \\
31 \\
53 \\
49 \\
34 \\
9\end{array}$ & $\begin{array}{r}0.5 \\
3.3 \\
16.9 \\
29.0 \\
26.8 \\
18.6 \\
4.9\end{array}$ \\
\hline
\end{tabular}

-The score (maximum 6) is derived from the correct answers to questions on changes to the breast with the menstrual cycle and menopause, number of lumps which are harmless $(8-9 / 10)$, women over 45 are at risk, cure improved by early detection, monthly self-examination.

Table 3 Women's general knowledge about the breast and breast cancer and the change over a 12 month period. Differences not significant. Percentages taken from women answering each question.

\begin{tabular}{|c|c|c|c|c|c|c|}
\hline \multirow{3}{*}{ Question } & \multicolumn{4}{|c|}{ Correct answers } & \multirow{3}{*}{$\begin{array}{l}\% \text { Change } \\
\text { in Edinburgh }\end{array}$} & \multirow{3}{*}{$\begin{array}{l}\% \text { Change } \\
\text { in Aberdeen }\end{array}$} \\
\hline & \multicolumn{2}{|c|}{ Edinburgh } & \multicolumn{2}{|c|}{ Aberdeen } & & \\
\hline & 1981 & 1982 & 1981 & 1982 & & \\
\hline \multirow{3}{*}{$\begin{array}{l}\text { Number of women in survey } \\
\text { 1. Can the following things cause any change to a woman's breasts? } \\
\text { Monthly cycle } \\
\text { Menopause } \\
\text { 2. Which of these pictures shows the true extent of the breast? } \\
\text { (1 of } 5 \text { diagrams) } \\
\text { 3. Out of every } 10 \text { women who find a lump in the breast, } \\
\text { how many have cancer? }\end{array}$} & 398 & 408 & 412 & 445 & & \\
\hline & $\begin{array}{l}309 \\
180\end{array}$ & $\begin{array}{l}331 \\
192\end{array}$ & $\begin{array}{l}328 \\
196\end{array}$ & $\begin{array}{l}349 \\
181\end{array}$ & $\begin{array}{l}3.5 \\
1.9\end{array}$ & $\begin{array}{l}-1.2 \\
-6.9\end{array}$ \\
\hline & 144 & 152 & 121 & 112 & $1 \cdot 1$ & $-4 \cdot 2$ \\
\hline $\begin{array}{l}\text { how many have cancer? } \\
\text { 4. Do you know if there are any other symptoms of breast cancer } \\
\text { apart from a lump? }\end{array}$ & 71 & 87 & 75 & 71 & $3 \cdot 5$ & $-2 \cdot 2$ \\
\hline $\begin{array}{ll}\text { Yes } \\
\text { Inverted nipple } \\
\text { Dimpling }\end{array}$ & $\begin{array}{r}129 \\
33 \\
8\end{array}$ & $\begin{array}{r}115 \\
29 \\
14\end{array}$ & $\begin{array}{r}137 \\
26 \\
10\end{array}$ & $\begin{array}{r}110 \\
24 \\
7\end{array}$ & $\begin{array}{r}-4.2 \\
-1.2 \\
1.4\end{array}$ & $\begin{array}{l}-8.6 \\
-1.0 \\
-0.8\end{array}$ \\
\hline \multicolumn{7}{|l|}{$\begin{array}{l}\text { 5. Do you know if any particular age groups are more prone to } \\
\text { breast cancer? }\end{array}$} \\
\hline $\begin{array}{l}\text { Over } 40 \\
40-65\end{array}$ & $\begin{array}{l}159 \\
130\end{array}$ & $\begin{array}{l}177 \\
110\end{array}$ & $\begin{array}{l}143 \\
109\end{array}$ & $\begin{array}{l}160 \\
110\end{array}$ & $\begin{array}{r}3.5 \\
-5.7\end{array}$ & $\begin{array}{r}1.3 \\
-1.8\end{array}$ \\
\hline
\end{tabular}


Edinburgh breast education campaign on breast cancer and breast self-examination: was it worth while?

As in our previous report, 5 we used these questions to define a mean score for knowledge in both surveys to compare the score according to age and socioeconomic status. Percentage changes in score between the surveys in both cities are given in table 4 . When expressed in this way, women in Edinburgh achieved a significantly greater improvement in score than women in Aberdeen after one year $(p<0.05)$. Age and social class did not influence the degree of difference found.

\section{Breast self-examination (BSE)}

The answers and percentage changes to questions about the technique and frequency of BSE are shown in table 5. Again, the changes are small and generally insignificant.

As previously described, ${ }^{5}$ we then calculated a score for "know-how" about BSE (ie, how and when to do it) according to age and social class. Results giving the percentage changes in score are shown in table 6 , and, once again, there is a significantly greater improvement after one year in the score in Edinburgh than in Aberdeen $(p<0.05)$.

The random surveys included questions on whether BSE had ever been tried and on the frequency with which it was performed. Similar questions are asked

Table 4 Change in mean general knowledge score over the 12 month period according to age and social class

\begin{tabular}{|c|c|c|c|c|c|c|c|c|}
\hline \multirow[b]{3}{*}{ Age $(y r)$} & \multicolumn{8}{|c|}{$\%$ Change in score } \\
\hline & \multicolumn{4}{|l|}{ Edinburgh } & \multicolumn{4}{|l|}{ Aberdeen } \\
\hline & $\begin{array}{l}\text { Professional } \\
\text { and } \\
\text { managerial }\end{array}$ & $\begin{array}{l}\text { Other } \\
\text { non } \\
\text { manual }\end{array}$ & $\begin{array}{l}\text { Skilled } \\
\text { manual }\end{array}$ & $\begin{array}{l}\text { Semi and } \\
\text { unskilled } \\
\text { manual }\end{array}$ & $\begin{array}{l}\text { Professional } \\
\text { and } \\
\text { managerial }\end{array}$ & $\begin{array}{l}\text { Other } \\
\text { non } \\
\text { manual }\end{array}$ & $\begin{array}{l}\text { Skilled } \\
\text { manual }\end{array}$ & $\begin{array}{l}\text { Semi and } \\
\text { unskilled } \\
\text { manual }\end{array}$ \\
\hline $\begin{array}{l}18-29 \\
30-49 \\
50+\end{array}$ & $\begin{array}{r}0( \pm 14) \\
2.9( \pm 8) \\
-1.8( \pm 13)\end{array}$ & $\begin{array}{r}10.4( \pm 11) \\
-5.1( \pm 8) \\
1.9( \pm 11)\end{array}$ & $\begin{array}{r}50.0( \pm 36) \\
16.7( \pm 14) \\
-2.2( \pm 18)\end{array}$ & $\begin{array}{r}-0.7( \pm 24) \\
-2.4( \pm 21) \\
40.8( \pm 31)\end{array}$ & $\begin{array}{l}-10.3( \pm 17) \\
-9.1( \pm 10) \\
-15.3( \pm 12)\end{array}$ & $\begin{array}{r}-2.0( \pm 9) \\
-5.3( \pm 7) \\
-15.6( \pm 13)\end{array}$ & $\begin{array}{r}-39.6( \pm 14) \\
2.2( \pm 10) \\
17.6( \pm 19)\end{array}$ & $\begin{array}{r}-21.4( \pm 17) \\
-3.8( \pm 13) \\
12.2( \pm 19)\end{array}$ \\
\hline
\end{tabular}

Standard error of the estimated percentage is shown in parentheses. Significant improvement $(p<0.05)$ in Edinburgh compared with Aberdeen.

Score derived from questions in table 3 (also see ref 5 ).

Table 5 Change in women's knowledge about the technique of breast self-examination

\begin{tabular}{|c|c|c|c|c|c|c|}
\hline & \multicolumn{2}{|c|}{ Edinburgh } & \multicolumn{2}{|c|}{ Aberdeen } & \multirow{2}{*}{$\begin{array}{l}\% \text { Change } \\
\text { in } \\
\text { Edinburgh }\end{array}$} & \multirow{2}{*}{$\begin{array}{l}\% \text { Change } \\
\text { in } \\
\text { Aberdeen }\end{array}$} \\
\hline & 1981 & 1982 & 1981 & 1982 & & \\
\hline $\begin{array}{l}\text { Number of women in survey } \\
\text { 1. About how often should a woman examine her breasts? }\end{array}$ & 398 & 408 & 412 & 445 & & \\
\hline $\begin{array}{l}\text { Monthly } \\
\text { 2. What is the best time for carrying out BSE? }\end{array}$ & 162 & 179 & 136 & 130 & $3 \cdot 2$ & -3.8 \\
\hline $\begin{array}{l}\text { After period } \\
\text { 3. What is the best position for BSE? }\end{array}$ & 78 & 80 & 63 & 52 & $0-0$ & -3.6 \\
\hline $\begin{array}{l}\text { Lying flat } \\
\text { 4. Do you know of anything about the breasts that may make BSE difficult? }\end{array}$ & $162^{-}$ & 205 & 158 & 164 & $9 \cdot 5 *$ & $-1 \cdot 4$ \\
\hline $\begin{array}{l}\text { Lumpy breasts } \\
\text { 5. Do you know which part of the finger a woman should use to do BSE? }\end{array}$ & 40 & 46 & 30 & 28 & 1.2 & $-1 \cdot 0$ \\
\hline $\begin{array}{l}\text { Flat parts } \\
\text { 6. How much pressure should a woman use in BSE? }\end{array}$ & 34 & 50 & 28 & 32 & 3.8 & 0.4 \\
\hline Firm & 109 & 120 & 99 & 111 & $2 \cdot 0$ & 0.9 \\
\hline
\end{tabular}

* $\mathrm{p}<0.05$

Table 6 Change in mean score of "know-how" over a 12 month period according to age and social class

\begin{tabular}{|c|c|c|c|c|c|c|c|c|}
\hline \multirow[b]{3}{*}{ Age (yr) } & \multicolumn{8}{|c|}{$\%$ Change in score } \\
\hline & \multicolumn{4}{|l|}{ Edinburgh } & \multicolumn{4}{|l|}{ Aberdeen } \\
\hline & $\begin{array}{l}\text { Professional } \\
\text { and } \\
\text { managerial }\end{array}$ & $\begin{array}{l}\text { Other } \\
\text { non } \\
\text { manual }\end{array}$ & $\begin{array}{l}\text { Skilled } \\
\text { manual }\end{array}$ & $\begin{array}{l}\text { Semi and } \\
\text { unskilled } \\
\text { manual }\end{array}$ & $\begin{array}{l}\text { Professional } \\
\text { and } \\
\text { managerial }\end{array}$ & $\begin{array}{l}\text { Other } \\
\text { non } \\
\text { manual }\end{array}$ & $\begin{array}{l}\text { Skilled } \\
\text { manual }\end{array}$ & $\begin{array}{l}\text { Semi and } \\
\text { unskilled } \\
\text { manual }\end{array}$ \\
\hline $\begin{array}{l}18-29 \\
30-49 \\
50+\end{array}$ & $\begin{array}{r}-7.7( \pm 17) \\
7.3( \pm 11) \\
6.7( \pm 15)\end{array}$ & $\begin{array}{r}10.0( \pm 12) \\
14.3( \pm 12) \\
9.7( \pm 13)\end{array}$ & $\begin{array}{r}-21.4( \pm 20) \\
10.3( \pm 14) \\
-20.8( \pm 22)\end{array}$ & $\begin{array}{l}40.9( \pm 52) \\
22.7( \pm 26) \\
43.8( \pm 40)\end{array}$ & $\begin{array}{r}-15 \cdot 2( \pm 19) \\
8 \cdot 8( \pm 15) \\
-21 \cdot 2( \pm 15)\end{array}$ & $\begin{array}{r}-6.2( \pm 11) \\
-17 \cdot 1( \pm 8) \\
-4.5( \pm 16)\end{array}$ & $\begin{array}{r}-12 \cdot 0( \pm 27) \\
0.0( \pm 11) \\
11 \cdot 1( \pm 21)\end{array}$ & $\begin{array}{r}-4 \cdot 3( \pm 27) \\
5 \cdot 0( \pm 32) \\
10 \cdot 3( \pm 25)\end{array}$ \\
\hline
\end{tabular}

The standard error of the estimated percentage is shown in parentheses. Significant improvement $(p<0.05)$ in Edinburgh compared with Aberdeen. 
Table 7 Comparison of the practice of breast self-examination in women aged 45-65 years in the various groups expressed as a percentage (number of women in parentheses)

Note: women surveyed in the two cities are different groups each year, while those attending for screening are the same women each year.

\begin{tabular}{|c|c|c|c|c|c|c|c|c|}
\hline & \multicolumn{4}{|c|}{ Random sampling of the population } & \multicolumn{4}{|c|}{ Women attending regularly } \\
\hline & \multicolumn{2}{|c|}{ Edinburgh } & \multicolumn{2}{|c|}{ Aberdeen } & \multicolumn{4}{|c|}{ Breast screening clinic } \\
\hline & 1981 & 1982 & 1981 & 1982 & 1980 & 1981 & 1982 & 1983 \\
\hline $\begin{array}{l}\text { Ever tried BSE (\%) } \\
\text { BSE every month (\%) }\end{array}$ & $\begin{array}{l}48(85) \\
11(19)\end{array}$ & $\begin{array}{l}56(92) \\
13(21)\end{array}$ & $\begin{array}{l}56(98) \\
11(19)\end{array}$ & $\begin{aligned} 41(81) \\
7(13)\end{aligned}$ & $\begin{array}{l}44(5613) \\
12(1531)\end{array}$ & $\begin{array}{l}72(8021) \\
34(4010)\end{array}$ & $\begin{array}{l}78(9899) \\
42(5330)\end{array}$ & $\begin{array}{l}77(4306) * \\
46(2572)^{*}\end{array}$ \\
\hline
\end{tabular}

*Based on the attendance by 5592 women.

routinely at the breast screening clinic at the women's annual visits. In table 7, the answers at the clinic are compared with those from the population in women of similar age. There was little change over 12 months in the random sample of women, but in women who are screened regularly there is a marked and significant increase, both in the trying of BSE and in those performing it monthly. We also asked women in the survey whether they had ever been screened, and $20 \%$ in Edinburgh said they had, compared with $5 \%$ in Aberdeen.

The change in scores of knowledge and know-how for the two cities are given in table 8. Interestingly, those not screened show an improvement in Edinburgh compared with Aberdeen, though their scores are generally lower than in the screened women.

\section{Discussion}

The campaign was low key and based on personal contact rather than using the media. Our objective was to raise public awareness and knowledge about the problem of breast cancer, but as the beneficial effects of health education campaigns have been questioned, 67 we planned a systematic evaluation from the beginning, mainly at cognitive and behavioural levels. This was done after 12 months, although the campaign itself was sustained for two years. This is in contrast to

Table 8 Comparison of women who said they had been screened with those had not

\begin{tabular}{|c|c|c|c|c|}
\hline & \multicolumn{2}{|l|}{ Edinburgh } & \multicolumn{2}{|l|}{ Aberdeen } \\
\hline & 1981 & 1982 & 1981 & 1982 \\
\hline $\begin{array}{l}\text { No. who said } \\
\text { screening* } \\
\text { Mean general }\end{array}$ & $87(22 \%)$ & $82(20 \%)$ & $16(4 \%)$ & $27(6 \%)$ \\
\hline $\begin{array}{l}\text { Screened } \\
\text { Not screened } \\
\text { Mean know-how }\end{array}$ & $\begin{array}{l}5 \cdot 80 \\
4 \cdot 98\end{array}$ & $\begin{array}{l}5 \cdot 92 \\
5 \cdot 20\end{array}$ & $\begin{array}{l}5 \cdot 62 \\
4 \cdot 95\end{array}$ & $\begin{array}{l}6 \cdot 14 \\
4 \cdot 56\end{array}$ \\
\hline $\begin{array}{l}\text { score: } \\
\text { Screened } \\
\text { Not screened }\end{array}$ & $\begin{array}{l}3.71 \\
2.89\end{array}$ & $\begin{array}{l}3.59 \\
3.27\end{array}$ & $\begin{array}{l}3.81 \\
2.72\end{array}$ & $\begin{array}{l}3.55 \\
2 \cdot 51\end{array}$ \\
\hline
\end{tabular}

"Not necessarily at breast screening clinic the intensive Southampton campaign which lasted only one month. ${ }^{8}$

At an individual level, we can confidently say that there was an improvement in knowledge among women who attended the talk both immediately afterwards and 12 months later in a selected group. This latter result may not be representative of the whole population, as these women were sufficiently interested to attend, agree to a postal questionnaire, and respond. We have estimated that the attendance at our talks at workplaces was about $50 \%$ on average of the workforce, some of whom could not attend because of other commitments, but many presumably because they chose otherwise.

At a population level, we carried out surveys on random samples of women also at 12 months. In retrospect, this was clearly too early, but the constraints of planning round a three year financial grant budget were repsonsible for our time schedule. Nevertheless, when we allowed for age and socioeconomic status, we found a small but significant improvement in general knowledge about the breast and techniques of breast self-examination in Edinburgh, compared with Aberdeen. We cannot, of course, be certain that this change was caused by our campaign, and we note the trend towards diminished knowledge in Aberdeen after a year. The result in Edinburgh was not due to greater numbers of women being screened, as there was an improvement in women who had not been screened.

There was little evidence of an increase in the number of women practising BSE, and only a small percentage said they carried it out monthly. This reluctance seems similar to a finding in Huddersfield where only a small proportion of women were willing to attend meetings. ${ }^{9}$ In our experience, women who attend regularly for screening are more likely to practise BSE. It is possible that they are more health conscious than others, or overreport because they wish to appear well motivated. It seems likely, however, that they practise BSE because they are more confident that their breasts are normal. ${ }^{10}$ If BSE is to be encouraged, as most GPs would wish, ${ }^{11}$ it is best 
taught in the context of a physical examination. In our survey, $75 \%$ of women in both Edinburgh and Aberdeen said they would have liked an examination first.

We are well aware that the evidence for the value of BSE is debatable. ${ }^{12}$ Some reports indicate a significant improvement in survival or stage in women who self-examine, ${ }^{1314}$ but others suggest no such improvement. ${ }^{15}$ It is interesting that the views of the health visitors employed on our campaign underwent a change. Initially enthusiastic about teaching BSE, they experienced increasing reluctance in performing it themselves. We have not read reports of staff reactions in other campaigns but note that in the short term in the Southampton campaign the staff did not get more anxious. ${ }^{8}$ Psychological barriers clearly exist, preventing regular BSE, but also many women do not feel particularly susceptible or vulnerable to breast cancer. In our random survey, only $5 \%$ of women spontaneously said they were worried about breast cancer, with no change after 12 months of the campaign. $^{5}$

At present our results indicate a marginal improvement in knowledge in Edinburgh and could therefore be counted as worth while. Its costs were not great and it could be reproduced. But if BSE is an end-point, then one-to-one teaching seems best, after the breasts have been found to be normal. Was it worth while for the women to whom we spoke? We were aware of their appreciation and had a strong impression that many women wished for more knowledge not just about breast cancer, but about their health in general. Because of this, we realised that promoting information about breast cancer might best be done in the context of general health. ${ }^{16}$ We did not try to assess attitudes but would be interested in knowing how attitudes to screening and BSE might differ between "fatalists and lifestylists" as recently described. ${ }^{17}$

There may still be long-term effects of our campaign. A study is in progress to determine whether there is any change in the proportion of women (who are not screened) who present with late stage breast cancer at diagnosis.

The Health Education Campaign was funded by the Cancer Research Campaign (Grant No SP1575 to MMR). We acknowledge with gratitude the help of many people, in particular the Working Group who advised us from the beginning: Dr Leila Watson and Mr John Davies from the Scottish Health Education group and Mr Mike Daube from the Department of
Community Medicine, University of Edinburgh. We thank Social and Community Planning Research for the meticulous care with which they carried out the interviews, and Grampian Health Board for their cooperation. Last, but not least, we thank all the women who so willingly filled in our questionnaires.

\section{References}

${ }^{1}$ Roberts MM, Alexander FE, Anderson TJ, et al. The Edinburgh randomised trial: Description of method. $\mathrm{Br} J$ Cancer 1984; 50: 1-6.

2 Roberts MM, French K, Robinson SE. The Edinburgh Breast Education Project. UICC Technical Reports 1984; 77: $39-48$.

${ }^{3}$ Beahrs OH, Shapiro S, Smart C, McDivitt RW. Summary report of the working group to review the NCI-ACS Breast Cancer Detection Demonstration Programme. $J$ Natl Cancer Inst 1979; 62: 642-709.

${ }^{4}$ Leathar DS, Roberts MM. Older women's attitudes towards breast disease, self-examination and screening facilities: communication implications. $\mathrm{Br} \mathrm{Med} J \mathrm{1985}$; 290: 668-70.

5 Roberts MM, French K, Duffy J. Breast cancer and breast self-examination: what do Scottish women know? Soc Sci Med 1984; 18: 791-7.

6 Williams BT. Are public health education campaigns worthwhile? Br Med J 1984; 288: 170-1.

${ }^{7}$ Gatherer A, Parfit J, Porter E, Vessey M, Is health education effective? London: Health Education Council, 1980.

${ }^{8}$ Christmas P, Nichols S. Don't take a chance! A public campaign to encourage the early reporting of breast symptoms. Health Educ J 1982; 41: 61-8.

${ }^{9}$ Philip J, Harris WG, Flaherty C, Joslin CAF, Rustage JH, Wijesinghe DB. Breast self-examination: clinical results from a population-based prospective study. $\mathrm{Br} J$ Cancer 1984; 50: 7-12.

${ }^{10}$ Pennypacker HS, Goldstein MK, Stein GH. Efficient technology of training breast self-examination. UICC Technical Reports 1983, 72. Public education about cancer pp 90-6.

${ }^{11}$ Kalache A, Roberts MM, Stratton I. Breast cancer: veiws of general practitioners on its detection and treatment. $J$ Roy Coll Gen Pract 1984; 34: 250-4.

12 Frank J, Mai V. Breast self-examination in young women: more harm than good? Lancet 1985; ii: 644-57.

${ }^{13}$ Foster RS, Costanza MC. Breast self-examination practices and breast cancer survival Cancer 1984 55: 432-7.

14 Turner J, Blamey R, Roy D, Odling-Smee W, Orwin G, Mackenzie G. Does a booklet of breast self-examination improve subsequent detection rates? Lancet 1984; ii: 337-9.

${ }^{15}$ Smith EM, Burns TL. The effects of breast selfexamination in a population-based cancer registry. Cancer 1985; 55: 432-7.

${ }^{16}$ Robinson SE, Roberts MM. A woman's health shop: a unique experiment. $\mathrm{Br} \mathrm{Med} J$ 1985; 291: 255-6.

${ }^{17}$ Pill R, Stott NCH. Choice or chance: further evidence in ideas of illness and responsibility for health. Soc Sci Med 1985; 20: 981-91. 